International Research Journal of Management, IT \& Social Sciences
Available online at https://sloap.org/journals/index.php/irjmis/
Vol. 5 No. 6, November 2018, pages: 40 51
ISSN: 2395-7492
https://doi.org/10.21744/irjmis.v5n6.336

\title{
Ideology in Tempo Magazine Advertising: A Critical Discussion Analysis
}

Muhamad Maimun ${ }^{a}$

Halus Mandala $^{\mathrm{b}}$

Arifuddin ${ }^{c}$

Article history:

Received: 5 July 2018

Accepted: 30 September 2018

Published: 29 October 2018

\section{Keywords:}

Advertising;

Critical;

Discourse structure;

Ideology;

Tempo magazine advertising;

\section{Abstract}

This research was conducted to describe and analyze the ideology and the structure of the text of advertising discourse in Tempo magazine which is in tone with Van Dijk's theory in the form of three structures (1) macro analysis, (2) superstructure, and (3) microanalysis. In this study, the analysis model used was the Van Dijk model. There are three dimensions in the discourse described by Van Dijk namely, text, social cognition, and social context. Critical discourse analysis of Van Dijk's model is not merely analyzing the text but also looking at the social structure existing in society. The ideology in the text of the advertising discourse in Tempo magazine is as follows: first, the ideology built-in messages delivery to the text of the Tempo magazine advertisement discourse; secondly, the explanation in the text is more accurate and detailed in the schematic section considered influential, third, the ideology of the text of the advertising discourse in Tempo magazine is a part of element of syntax, semantic, and rhetorical. Ideology in the text of the advertising discourse in Tempo magazine is very dependent and influential in the social, political, economic, and other contexts. In this study, there are study aspects that can be relevant to the study of discourse analysis in higher education, namely a model for analyzing texts based on the CDA approach. The results of this study can be used as references to analyze written texts and in linguistic analysis.

2395-7492@ Copyright 2018. The Author. This is an open-access article under the CC BY-SA license (https://creativecommons.org/licenses/by-sa/4.0/) All rights reserved.

\section{Author correspondence:}

Muhamad Maimun,

Mataram University, Indonesia,

Email address: muhamadmaimun74@gmail.com

${ }^{\text {a }}$ Mataram University, Indonesia

b Mataram University, Indonesia

${ }^{\mathrm{c}}$ Mataram University, Indonesia 


\section{Introduction}

The development of mass media communication is currently growing rapidly. Along with these developments, the community actively uses it for various interests in social life, both as a means of promotion, communication, and even educational media from elementary to tertiary level. Mass media is not only used to socialize in the community but it has become a media and strategic tool to achieve various goals. Economic, political, cultural interests, even as a means of spreading ideology can be achieved through mass media. This is believed to be based on the media having various functions such as the function of information, education, entertainment and functioning to influence the audience. One of the products that are actively produced by the mass media is advertising.

It can be said that the advance of a mass media (magazine) depends very much on how much the consumer's (public) interest in the mass media (magazine) is. This fact should be accommodated by producers (advertisers) in order to present advertisements as attractive as possible and use language in tone with the expectations of the reader.

Besides, the reason for choosing Tempo Magazine as a data source is, (1) Tempo magazine is one of the print media that has the largest print circulation, (2) Tempo magazine is a national-level magazine with high-quality products to reach the upper middle target, (3) based on field observations Tempo magazine is a print media that controls $68 \%$ of the weekly news magazine market.

Critical Discourse Analysis of Media is a conclusion from the point of view that the author put forward about the media which comes into contact with content analysis, framing analysis, discourse, and semiotics. Authors also begin to understand that the ability of the community in sorting media and interpreting meaning becomes a kind of shield limiting exposure to information from various media.

This article is intended to be used a reference to write a scientific work related to mass media focusing on a critical paradigm in order to criticize the construction of media discourse that nowadays becomes a media to socialize and a media to pour the idealism of the actor work on media. The writer expects that the benefits can be seen comprehensively from the aspect of society.

Critical Discourse Analysis of Media is a form of conclusion from the point of view that the author put forward about the media, which comes into contact with content analysis, framing analysis, discourse, and semiotics. Authors also begin to understand that the ability of the community in sorting media and interpreting meaning becomes a kind of shield limit exposure to information from various media.

\section{Materials and Methods}

The data analysis method used is the qualitative descriptive method by outlining the data explicitly without using quantitative formulas with the aim of finding the percentage of domination of the text structure and the process of persuasive discourse.

Data collection in this study uses documentation method. Documentation is done by copying the magazine which is used as the main data. The data collection in this study was done by copying the tempo magazine ad, reading the whole Tempo Magazine, sorting the clause and the vocabulary contained in the advertising discourse in Tempo Magazine.

The results of data analysis are presented using two methods namely formal and informal methods. Formal methods are used to present the results of data analysis using tables or schemes. Meanwhile, the informal method is done by presenting the data described in sentence or paragraph structure.

Meanwhile, the informal method is done by presenting the data described in sentence or paragraph structure.

\section{Theoretical Framework}

Based on the content and function of the advertising discourse on the print media, there are three parts namely (1) the initial section, (2) body (explanation), and (3) closing. The discourse of advertisement persuasion in print media displays parts such as the beginning (title, subtitle), body, and closing section (affirmation, action). The body of the discourse is the part that must be present, while the initial part and cover are relative or optional. The initial part of the discourse is a title and subtitle. The title of the discourse contains the name of the print media, solicitation, promises, notifications and the benefits of reading magazines/newspapers and it serves to attract the attention of the reader.

Maimun, M., Mandala, H., \& Arifuddin, -. (2018). Ideology in tempo magazine advertising: a critical discussion analysis. International Research Journal of Management, IT and Social Sciences, 5(6), 40-51. 
Discourse in Indonesian is used as the equivalent (translation) of the word discourse in English. Etymologically, the word "discourse" comes from the Latin discursus "run here and there". The word discourse is derived from the word discursus. The structure of discursus is constructed from dis and currere "run, walk fast" Wabster (in Badara, 2002: 1; compare Setiawan, 2018). Discourse is then adopted as a linguistic term. In linguistics, discourse is understood as a lingual unit that is above the level of sentences (Badara, 2012: 2).

Referring to the Linguistic Dictionary of the Language Council and Library (2008: 5), discourse is translated as discourse, a complete and highest language unit consisting of rows of words or sentences, the same as in the oral or written structure used as a material for linguistic analysis.

Kridalaksana (in Setiawan, 2016: 69) discusses that discourse is the most complete language unit in the highest grammatical hierarchy and is the highest or the largest grammatical unit. Discourse is realized in the structure of a complete essay such as novels, short stories, or prose and poetry, encyclopedias series and others as well as paragraphs, sentences, phrases and words that carry a complete mandate. Therefore, discourse is a linguistic unit that is bigger than a sentence or clause. Discourse is a series of related sentences, which connect one proposition to another, to structure one unit so that the matching meaning is structured between the sentences. The most complete and highest or largest language unity above the sentence or clause with high coherence and high cohesion that is continuous, capable of having a real beginning and end, delivered orally or in writing J.S Badudu (see Eriyanto, 2001: 2).

Broadly speaking, it can be concluded that the notion of discourse is the most complete language unit of phonemes, morphemes, words, clauses, sentences with high continuous coherence and cohesion being able to have a real beginning and end, delivered orally or in writing. Verbal and can also be written, but the terms must be in one series and developed $\mathrm{d}$ by more than one sentence.

Discourse analysis is a general term used in various disciplines with a variety of understandings. Discourse analysis is a study related to language use. According to the U.S Hikam (in Eriyanto. 2001: 4), there are three paradigms of discourse analysis in seeing the language. First, the view of positivism-empirical; second, the view of constructivism view; and the critical views.

Lukmana, Aziz and Kosasih (2006: 12; in Eriyanto, 2001) said that Critical Discourse Analysis has different characteristics from "non-critical" discourse analysis tending to describe only the structure of a discourse. Critical Discourse Analysis acts further including by exploring the reasons why a discourse has a certain structure, which in turn will lead to an analysis of social relations between the parties included in the discourse.

Critical discourse analysis contains theories and methods that can be used to conduct empirical studies of the relationships between discourse and social and cultural development in different social domains (Jorgensen and Philips, 2007: 114). The aim of critical discourse analysis is to explain the linguistic dimensions of discourse on social and cultural phenomena and the process of change in current modernity (Jorgensen and Philips, 2007: 116; in Setiawan, 2018; Sinar, 2012; Saragih, 2013).

Fairclough and Wodak in Eriyanto (2001: 7) argue that critical discourse analysis sees discourse on the use of language in speech and writing as a structure of social practice. Discourse as a social practice causes a dialectical relationship between certain discursive events with the situation, institutions, and social structures that structure it. Discourse practice can be an ideological effect.

Thus, CDA is a theory for conducting empirical studies about the relations between discourse and socio-cultural development. To analyze discourse, one of which can be seen in the linguistic area by paying attention to the sentences contained in the text (magazine) can use critical discourse analysis theory.

Critical discourse analysis is also a study that not only studies language from linguistic aspects but also studies the language by associating language with social context. The context, in this case, is all situations and things that are different outside the text and affect the use of language for certain practical purposes, including the practice of power (Badara, 2013: 28; Saragih, 2001).

Context is an element that is a means to clarify a purpose. The means in question are parts of expressions that support the clarity of intentions and situations related to an event. The context in the form of a part of the expression that can clarify intent is called co-text. The context in the form of situations related to common events called context (context) (Hallyday and Hasan, 1992: 29; Halliday, 1994; 2004) Co-text and context in discourse analysis are two complementary things. Thus, reviewing the discourse is very useful to understand the meaning or purpose of using the real language.

The context of discourse is structured by various elements, namely the situation, speaker, listener, time, place, scene, topic, event, mandate structure, code, and channel (Sugono, 2013). The context of the discourse includes the following. 
a) Physical context includes the place where the use of language in a community, the object presented in the communication event and the action or behavior rather than the role in the communication event.

b) Epistemic context or background of knowledge that is known both by the speakers and listeners.

c) The linguistic context consists of sentences or utterances preceding a particular sentence or speech in a communication event.

d) Social context is a social relation and setting complementing the relationship between speaker and listener (speech partner).

\section{Results and Discussions}

\subsection{Structure of Discourse Text in Tempo Magazine}

a) Macro Structure of Discourse (Thematic)

Dalam struktur wacana makro yang dimaksud dalam teks Iklan ini adalah struktur wacana makro bagian tematik. In the macrostructure of discourse referred to in the text this ad is a thematic part of the macrostructure of discourse.

Thematic

\begin{tabular}{|l|l|}
\hline Theme/Topic & Subtopic \\
\hline \multicolumn{2}{|l|}{ Data 1 } \\
\hline $\begin{array}{l}\text { The beauty of tourism destinations in Malaysia } \\
\text { with diverse cultures and culinary variety. }\end{array}$ & $\begin{array}{l}\text { 1. Malaysia is known as a country various races and } \\
\text { religions. }\end{array}$ \\
& $\begin{array}{l}\text { 2. Geographically, Malaysia has cultural diversity } \\
\text { 3. Much historical tourism objects or destination in Malaysia. }\end{array}$ \\
\hline
\end{tabular}

\begin{tabular}{|c|c|}
\hline Theme/Topic & Subtopic \\
\hline Data 2 & \\
\hline $\begin{array}{l}\text { Lenovo launched an innovation of the VIBE P1 } \\
\text { Turbo smartphone with a powerful battery. }\end{array}$ & $\begin{array}{l}\text { 1. The cellphone is created for consumers with high mobility } \\
\text { who have the need to always be connected to the Internet } \\
\text { and remain productive but do not have the opportunity to } \\
\text { charge the battery. }\end{array}$ \\
\hline
\end{tabular}

Themes are core ideas, summaries, or the main parts of a text. The theme of the advertisement from data 1 to data 2 is as follows: (data 1) "The beauty of tourism destinations in Malaysia with diverse cultures and culinary variety". (data 2) "Lenovo launched an innovation of the VIBE P1 Turbo smartphone with an extra-powerful battery." This theme supports the development of the next subtopic as can be seen as follows. (Data 1) 1. Malaysia is known as a country various races and religions. 2. Geographically, Malaysia has a cultural diversity. 3. Much historical tourism object or destination in Malaysia. (Data 2) 1. This phone is created for consumers with high mobility who have the need to always be connected to the Internet and remain productive but do not have the opportunity to charge the battery. This cell phone is created for consumers with high mobility who have the need to always be connected to the Internet and remain productive but do not have the opportunity to charge the battery.

b) Super Structure (Schematic)

Data 1

\begin{tabular}{|l|l|}
\hline \multicolumn{2}{|c|}{ Summary } \\
\hline Tittle & Lead \\
\hline $\begin{array}{l}\text { Heaven in Southeast } \\
\text { Asia }\end{array}$ & $\begin{array}{r}\text { 1. Malaysia is known as a country with various races and religions. Various peoples, such } \\
\text { as Malays, Indians, Chinese, and other ethnic groups, grew up in this country. This } \\
\text { makes it multicultural. Multiculturalism makes Malaysia culinary paradise and home } \\
\text { to hundreds of colorful festivals. }\end{array}$ \\
\hline \multicolumn{2}{|c|}{ Story } \\
\hline Situation & Comment \\
\hline
\end{tabular}

Maimun, M., Mandala, H., \& Arifuddin, -. (2018). Ideology in tempo magazine advertising: a critical discussion analysis. International Research Journal of Management, IT and Social Sciences, 5(6), 40-51. https://doi.org/10.21744/irjmis.v5n6.336 


\begin{tabular}{l|l}
$\begin{array}{l}\text { Cultural diversity makes Malaysia a festival } \\
\text { and culinary paradise. }\end{array}$ & $\begin{array}{r}\text { 1. The attraction of the night market is to enjoy the culinary and } \\
\text { its atmosphere. Food is abundant with various types of delights. }\end{array}$ \\
\hline
\end{tabular}

The part of the text is the lead part of summary where the lead is very important in the delivery of messages, either in the form of news texts or advertising discourse texts that aim at finding out the core summary of the text content. The lead in this ad text illustrates how the situation in a region or country (Malaysia) has various ethnicities, religion, and race growing in this country such as Malay, Indian, Chinese, and other ethnicities. This fosters multiculturalism that makes Malaysia part of a colorful culinary and festival paradise. All of these things became points in the ad text so that the title "Heaven in Southeast Asia" was raised because the Malaysia state was part of the Asian country.

The next part of the Summary is the story containing the overall contents of a news text or text of the advertising discourse. The Story consists of situations and comments. The situation in this ad is "cultural diversity makes Malaysia a festival and culinary festival". The next part of the situation is the main part/thing that is displayed in an advertisement purposing to persuade and influence the reader or consumer to own, use, and/or buy the goods or services offered. This comment section is an assumption from the writers or producers of advertisements where the comments from the ad text above are "The attraction of the night market is to enjoy the culinary and the atmosphere. Food is abundant with various types of delights". This can be commented on by readers because it describes a situation that is not only an illusion. In accordance with the assumption of the ad text that is the attraction of several places depends on the situation, circumstances and various types of enjoyment so that it can provide a special attraction from the ad text in the Tempo magazine. The only aim is to show a territory of the country (Malaysia). In the text of this ad, it is only focused on Malaysia with different eminence from other countries in Southeast Asia.

\section{c) Micro Structure of Discourse (Semantics)}

In the microstructure of discourse referred to in the text of this advertisement is a semantic microstructure of discourse. Semantics has a section between background, details, intentions, and presuppositions.

1. Background

\begin{tabular}{|l|l}
\hline Data 1 & Multiculturalism makes Malaysia a culinary paradise and home to hundreds of colorful festivals.
\end{tabular}

The background is the most important element in a discourse text, either Ad text or news because the background supports and gives meaning to a situation. The background presented in this ad text is "Multiculturalism makes Malaysia a culinary paradise and home to hundreds of colorful festivals". The background is a part that describes the state of a place and event, so this is very supportive as a background to be included in the ad text in Tempo magazine with the title "Heaven in southeast Asia". Based on many cultures owned by the Malaysian state so as to form a diversity of cultures from various countries, this has become a form of unity of its own culture and part of the superiority of the Malaysian state. The background illustrates that with a multicultural state of Malaysia showing culinary richness and diversity that is an attraction for Malaysia. This is a form of persuasive statement to persuade visitors or tourists to visit Malaysia.

\begin{tabular}{|l|l|}
\hline \multicolumn{2}{|c|}{ Background } \\
\hline Data 2 & $\begin{array}{l}\text { The launch of innovations in the Power Series (Power Player) line of Lenovo products, } \\
\text { namely the VIBE P1 Turbo smartphone with extra-powerful batteries. }\end{array}$ \\
\hline
\end{tabular}

The background in this second data can be seen in the data table above. The background tells about how the quality of one Lenovo product cell phone has an extra-powerful battery. The exposure of the advantages of a cell phone that has an extra powerful battery is the background that is raised in the text of the advertising discourse in Tempo magazine. The background was deliberately raised by the ad with the aim of influencing and persuading consumers to use, buy, and have a type of product with the launch of innovations from the Lenovo product. On the other hand, the background of this second data is the emergence of the quality of the latest Lenovo innovation products and not the issue of the selling price of the product that was raised. 
d) Micro Structure of Discourse (Syntax)

The microstructure of discourse in this ad text is the syntactical microstructure of discourse. Syntax has parts including coherence, sentence form, and pronouns. These sections will be described as follows.

1. Coherence

\begin{tabular}{|l|l|}
\hline \multicolumn{2}{|c|}{ Conjunction } \\
\hline Data 1 & $\begin{array}{l}\text { The New Mazda CX-5 is also equipped with the hill launch to assist feature which can hold the car } \\
\text { when stopping on the ascending road so as to avoid the vehicle moving backward. }\end{array}$ \\
\hline
\end{tabular}

The findings of the data can be seen in the data table above which includes part of the syntactic structure of discourse, namely the element of coherence because coherence is an interconnection between words or between texts in the text. Where in the data table above there are two clauses that have different meanings and facts, we can see the following clause "The New Mazda CX-5 is also equipped with the hill launch to assist feature which can hold the car when stopping on the ascending road so as to avoid the vehicle moving backward". With the use of coherence "so" that serves as a conjunction that marks the effect. The conjunction "so" is used to relate one clause to another in order to have a causality relationship and become meaningful. In this case, it is used to connect the clause. "The New Mazda CX-5 also features the hill launch assist feature which can hold the car when it stops on the uphill road "and the clause" avoids the vehicle moving backward".

\section{Conditional Coherence in Sentences}

\begin{tabular}{|l|l|}
\hline \multicolumn{2}{|c|}{ Conditional Coherence in Sentences } \\
\hline Data 1 & $\begin{array}{l}\text { 1. Melaka has several places that are worth to visit, such as Fort St. John's Fort; Jonker Walk, a } \\
\text { heaven for collectors of antiques; and St Paul's Hill (A'Famosa). }\end{array}$ \\
\hline Data 2 & $\begin{array}{l}\text { 1. He revealed that various improvements made during 2015 would certainly be a strong } \\
\text { fundamental in supporting business expansion in 2016 where Bank DKI was committed to fully } \\
\text { support the Jakarta Provincial Government's program. }\end{array}$ \\
\hline
\end{tabular}

This data explains the use of clauses as explainers associated with conjunctions such as "which, or where" conjunctions. This can be seen in the data above which is a conditional coherence category. If we pay attention to this, the problem is clear where the usage of clauses as explainers of the next sentence serves to provide an explanation of the purpose of the previous sentence. All of these things need to be displayed in a news or advertisement to provide a more detailed understanding of the use of the clause.

\section{Sentence Form}

The form of sentences is part of the syntax that describes or connects logical thinking. This can be seen in the data table below.

\begin{tabular}{|l|l|l|}
\hline The form of Sentence & \multicolumn{1}{c|}{ Sentence } \\
\hline Data1 & Deductive & $\begin{array}{l}\text { Melaka has several places that are worth to visit, such as Fort St. John's Fort; Jonker } \\
\text { Walk, a heaven for collectors of antiques; and St Paul's Hill (A'Famosa), a fort built } \\
\text { during the Portuguese occupation of Melaka in 1511-1641 to maintain its colonial } \\
\text { power in the far east. }\end{array}$ \\
\hline
\end{tabular}

The data found at number one shows the use of sentence form used in news and advertisement submission, the use of sentence form in the text explains the situation of something general.

\section{Pronoun}

The pronoun is a very important thing in the delivery of the message, the goal is to manipulate language by creating an innovative community. Pronoun also determines one's position in the discourse. This can be seen in the data table below.

Maimun, M., Mandala, H., \& Arifuddin, -. (2018). Ideology in tempo magazine advertising: a critical discussion analysis. International Research Journal of Management, IT and Social Sciences, 5(6), 40-51. 


\begin{tabular}{|l|l|}
\hline \multicolumn{2}{|c|}{ Sentences } \\
\hline Data 1 & 1. When you are braking hard, the brake lights will blink quickly to warn the driver behind. \\
\hline Data 2 & $\begin{array}{l}\text { 2. He revealed that various improvements made during 2015 will certainly be a strong fundamental } \\
\text { in supporting business expansion in 2016 where Bank DKI is committed to fully support the } \\
\text { Jakarta Provincial Government's program. }\end{array}$ \\
\hline
\end{tabular}

The data found in the table above is a fine-tipped pronoun that is addressed to someone both the reader and the owner of the text, such as the pronouns "Anda, ia" (you, he). The word "Anda" (ÿou) shows a choice of subtle words that are addressed to someone, in this case, the consumer to be more interested and respectful or honored.

e) Micro Structure of Discourse (Stylistic)

The microstructure of discourse to in the text of this ad is the stylistic microstructure of discourse section. Stylistics has the lexicon part.

\section{Lexicon}

Lexicon is a language component that contains all the information about the meaning and usage of words in language, the lexicon also means the wealth of words that a language has so that the lexicon is the main attraction in communicating because lexicon elements indicate how a person uses the right diction according to the situation and conditions to deliver news, messages, and others both in the disclosure of actual information and facts. This can be seen in the data table below.

\begin{tabular}{|l|ll|}
\hline \multicolumn{2}{|c|}{ Sentences } \\
\hline Data1 & 1. & Malaka has several places worth to visit \\
& 2. & Travelers or tourists can visit Batu Caves in Selangor which is a popular tourism object there \\
\hline Data 2 & 1. & VIBE P1 Turbo smartphone with an extra-powerful battery \\
\hline
\end{tabular}

The finding of the data in the table above is the lexicons used in the first data such as words "famous and popular" become the question, why is the choice of this word raised? Because, in promoting a product, item, or service must be adjusted to the public or readers, whether the information submitted is local, national, or international. In the data above the message or information submitted is national so that the choice of words used must use popular words and easily understood means that advertisers and managers of mass media advertisements do not convey messages and information with words that are difficult for the public and consumers to understand.

f) Micro Structure of Discourse (Rhetoric)

1) Graphic

Graphic elements are a highlight to emphasize the purpose of something conveyed that can be observed in the text. The graphic forms in question can also be seen in the following data table below.

\begin{tabular}{|l|c|}
\hline Data 1 & Photo \\
\hline Data2 & Photos and use of capital letters \\
\hline Data3 & Photos and use of capital letters \\
\hline Data4 & Photo, capital letters, graphics in form of a number. \\
\hline Data 5 & Photo and larger font sizes \\
\hline
\end{tabular}

The data in the table above are the findings of the data contained in the advertisements in Tempo magazine which can be seen in the next attachment. In this section, the researcher can describe the purpose and reason behind the graphic prominence which is part of the rhetoric. This becomes necessary in the submission of news texts or advertisements as additional material to show the facts to be conveyed or to be of concern to the readers, namely consumers. Similarly, the use of capital letters shows the same emphasis on certain goals and purposes. 
1. Metaphor

The metaphor is part of the rhetoric, which is part of a discourse. In the discourse text, besides the delivery of the main message through the text, there is also a figure of speech, an expression that has meaning outside the text as if to spice up the news or advertisement. This can be seen in the data table below.

\begin{tabular}{|l|l|}
\hline \multicolumn{2}{|c|}{ Metaphorical Sentences } \\
\hline Data 1 & $\begin{array}{l}\text { 1. Various peoples, such as Malays, Indians, Chinese, and other ethnic groups, grew up in this } \\
\text { country }\end{array}$ \\
\hline
\end{tabular}

Based on the findings of the data in the table above, in the use of messages in advertisements there is a metaphor part including the word "grow" meaning that can be linked or related. That word grows can be related to plant matter but the meaning of growing here is developing.

\subsection{Ideology Representation of Discourse Text in Tempo Magazine}

Researchers can assess that the discourse text of ads on Tempo magazine advertisements can be observed by looking at the use of language or the diction of the word used. All of these things are found in several texts consisting of several elements used in the delivery of messages to the realm of macro discourse structures, superstructures, and micro. These discourse structures, have certain parts that want to be revealed in the text of the discourse of either news or advertising. Based on this, the researcher can analyze that the ideology in the text of the advertising discourse in Tempo magazine is as follows: first, the ideology that was built in the delivery of messages to the text of the Tempo magazine advertising discourse, the theme or title that was packaged in persuasive/interesting language. The data found in the macro section of the theme can be seen in the following data.

a) Data of Macro Structure Part

Theme 1

Heaven in Southeast Asia

The findings above are a form of part of the macrostructure that has meaning outside the text, this creates a different interpretation from all parties, both writers and readers. Why is this theme raised in the advertisement? Because the author believes that this theme is adapted to the context in which Malaysia really has cultural, racial and religious diversity. All of these things have become the belief of the ad writer by displaying the theme "Heaven in Southeast Asia" which describes one of the situations and conditions in Southeast Asia (Malaysia), where this is the context of the ad text.

Theme 2

News Mazda CX-15 Presents Exceeding Expectation

The word "exceeding expectations" has a meaning that is more than disease medicine or fulfilling family needs when it requires things that do not yet exist, so advertising manufacturers believe that the presence of the brand "Nes Mazda Cx-15" can answer the need for consumers to use or buy types car or vehicle as advertised.

Tema 3

Lenovo Launched Cellphone with Powerful Battery

The word "launch" means holding or removing a product, indeed the word "launch" is used for something that has extreme folds such as rocket launchers, missiles, and others. This is an attraction and gives the author the confidence that with the diction, of course, can make readers interested in the type of product advertised. The word "powerful battery" means that the battery has a more durable power than other phones have.

Maimun, M., Mandala, H., \& Arifuddin, -. (2018). Ideology in tempo magazine advertising: a critical discussion analysis. International Research Journal of Management, IT and Social Sciences, 5(6), 40-51. https://doi.org/10.21744/irjmis.v5n6.336 
b) Parts of Micro Structure

The ideology built in the text of discourse depends on the community or consumers and the ideology built by the news-bearers or advertisements themselves because by displaying some elements of the discourse structure that have been packaged as well as possible by taking into account the situation and conditions in considering the choice of word and geographical choices, it becomes the main attraction for readers.

\subsection{Relevance of CDA with Discourse Learning in Higher Education}

The orientation of lecturing in Indonesian language courses in higher education is directed towards the ability of students to analyze texts, both oral texts, and written texts and good and correct language skills. In general, the ability of students to analyze texts can be reviewed in terms of language as a reality of good and correct language use. Thus, the results of this study certainly have relevance to the learning of discourse in universities. In this case, it can certainly be seen from the object side of the Tempo magazine advertising discourse text study that is in the form of written text which is part of the discourse so that it can be respected by learning discourse in universities through three aspects, namely 1) Learning Aspects. 2) Significancies Aspects and 3) Curriculum aspects.

\subsection{Discussion}

Classification of data found by researchers from the text of the advertisement includes, first, part of the macrostructure. In this study researchers only took four themes, namely 1 . Heaven in south-east Asia. 2. Lenovo launched the cellphone with extra-powerful battery. 3. New Mazda is beyond expectation. 4. DKI Bank develops business with DKI business circles. Next, the super part of the structure consisting of introduction, content, concluding and conclusions. In this case, the researcher has described and it can be seen in the previous section. Second, the microstructure section consists of four parts, namely 1. Semantics 2. Syntax 3. Stylistics and 4. Rhetoric. Third, the super part of the structure consists of a schematic. The schematic also has the most important parts including Summary and Story, a summary consisting of the title, lead, and story consisting of situations and comments. All the data above has been described by the researcher and can be seen in the previous section.

The part of macro and microstructure is a critical discourse analysis approach in analyzing the discourse text which consists of one unit which cannot be separated in conveying a message both news and advertising in this case Tempo magazine, the aim of researchers in taking steps to analyze the data using critical discourse analysis approach (AWK) is to provide a detailed explanation of what the intent or purpose contained in the text is presented by the news or advertising managers.

The ideology section, besides the data found in the ad text, there is a part of the social context or outside the text which is a supporter of one of the texts on both news and advertising discourse. This is also the part or side of the ideology that is built by the news writer or advertisement in presenting a message that is the main attraction both in terms of meaning and interpretation for the advertising writers and readers. All data that is outside the text or social context is very influential in delivering the text of news discourse and advertisements because, by the ideology built by the author, it is very influential on the readers both in this case and the community in general.

Based on all data findings and data calcification techniques that have been described, researchers can provide input as a supplement in the process of teaching and learning and as a reference to the next author by linking all of these things in the process of teaching and learning in higher education or the relevance of research with learning discourse analysis in terms of analytical techniques using van Dijk's critical discourse analysis approach. All of these things as a form of the effort of the researcher in applying a text analysis technique of discourse both in learning discourse in higher education and in the sense that this analytical approach is a reference for students in analyzing the text of both news and advertising discourse. In this study, indeed the red thread is focused on the problem of text discourse, namely the ad text on Tempo magazine as a source of data and research objects. Furthermore, in analyzing the data using a critical discourse analysis approach van Djik's version, the researcher hopes to provide a great benefit for students as a reference in improving understanding of critical discourse analysis learning or courses and as a reference for subsequent writers who conduct research with a critical discourse analysis approach where the author made all of these things as the full essence in this study. 


\section{Conclusion}

Based on the description and analysis of data that has been done before, it can be concluded that the type of discourse analysis identified in the text of the ad discourse on Tempo magazine which is in line with Van Dijk's theory consists of three forms of structure (1) macro analysis, (2) superstructure, and (3) microanalysis. Macro (thematic) analysis consists of themes/topics and subtopics. Superstructure analysis (schematic) consists of a summary and story, while summary consists of titles and leads, while stories consist of situations and comments. Furthermore, for microanalysis, it consists of: smart (background, detail, intent, presupposition), syntax (coherence, sentence form, pronoun), stylistic (lexicon), and rhetoric (graphic and metaphor). The ideology that is owned by the owner of the advertisement or news becomes a reinforcing element in the delivery of the text of the advertisement or news discourse. In this study, there are study aspects that can be relevant to the study of discourse analysis in high schools, namely a model of analyzing texts based on the CDA approach, especially in analyzing mass media texts focused on the benefits of research results as a form of contribution to learning discourse in higher education. The form of the contribution of research results to learning discourse in universities is the result of this research can be used as a reference in analyzing written texts and on linguistic analysis, the sign and meaning contained in the text of the discourse using the Van Dijk CDA model approach.

Conflict of interest statement and funding sources

The authors declared that they have no competing interest. The study was financed by personal funding.

\section{Statement of authorship}

The authors have a responsibility for the conception and design of the study. The authors have approved the final article.

\section{Acknowledgments}

Researchers would like to thank all those who have contributed to the completion of this study. To my parents and wife who always pray, encourage, and motivate me during my study. The researcher also expresses his gratitude to all comrades for their solidarity during his master's education.

Maimun, M., Mandala, H., \& Arifuddin, -. (2018). Ideology in tempo magazine advertising: a critical discussion analysis. International Research Journal of Management, IT and Social Sciences, 5(6), 40-51. 


\section{References}

Ali, M. (2008). Kamus Besar Bahasa Indonesia (KBBI) Edisi Ke Empat. Jakarta: PT. Gramedia Pustaka Utama.

Badara, A., \& Hum, M. (2014). Analisis Wacana: Teori, Metode, dan Penerapannya pada Wacana Media. Prenada Media.

Badudu, J. S., \& Zain, S. M. (1994). Kamus Besar Bahasa Indonesia. Jakarta: Pustaka Sinar Harapan.

Eriyanto. (2001). Analisis wacana: pengantar analisis teks media. LKiS Yogyakarta.

Fairclough, N., \& Wodak, R. (2005). Critical discourse analysis. na.

Halliday, M. A. K., \& Matthiessen, C. M. (2008). An introduction to functional grammar (pp. 144-157). London: Edward Arnold.

Halliday, M. A. K., Matthiessen, C., \& Halliday, M. (2014). An introduction to functional grammar. Routledge.

Halliday, M. A. K., Ramlan, M., Hasan, R., \& Tou, A. B. (1992). Bahasa, konteks, dan teks: aspek-aspek bahasa dalam pandangan semiotik sosial. Gadjah Mada University Press.

Hikam, M. A. (1996). Demokrasi dan civil society. Lp3es.

Jorgensen, M. W. dan Louise J. Philips. 2007. Discourse Analysis: Theory and Method.

Kridalaksana, H. (1998). Introduction to word formation and word classes in Indonesian (No. 1). Fakultas Sastra Universitas Indonesia.

Lukmana, I., Aziz, E. A., \& Kosasih, D. (2006). Makna interpersonal dalam interaksi. Linguistik Indonesia, $24,11$.

Saragih, A. (2006). Bahasa dalam Konteks Sosial: Pendekatan Linguistik Fungsional Sistemik terhadap Tata Bahasa dan Wacana. Medan: Sekolah Pacasarjana Universitas Negeri Medan.

Saragih, A. (2013). Introducing systemic functional grammar of English. Medan: English Department Faculty of Languages and Arts The State University of Medan UNIMED.

Saragih, A. (2013). Semiotik Bahasa: Tanda, Penanda dan Petanda dalam Bahasa. Universitas Negeri Medan: Program Pascasarjana.

Setiawan, I. (2016). Morfem Suprasegmental Pada Teks Pidato Pengunduran Diri Prabowo-hatta Dalam Pilpres Tahun 2014: Sebuah Tinjauan Fonologis. Aksara, 28(1), 61-76.

Setiawan, I., Laksana, I. K. D., Mahyuni, -, \& Udayana, I. N. (2018). System of modality on the text of Indonesian presidential candidates debate on the period of 2014-2019. International Journal of Social Sciences and Humanities, 2(1), 157-170.

Sinar, T. S. (2012). Teori \& Analisis Wacana: Pendekatan Linguistik Sistemik Fungsional. Medan: Mitra Medan. Wabster, J. (1897). Jock wabster snowed up. The Dundee wasp, (7), 122-123. 


\section{Biography of Authors}

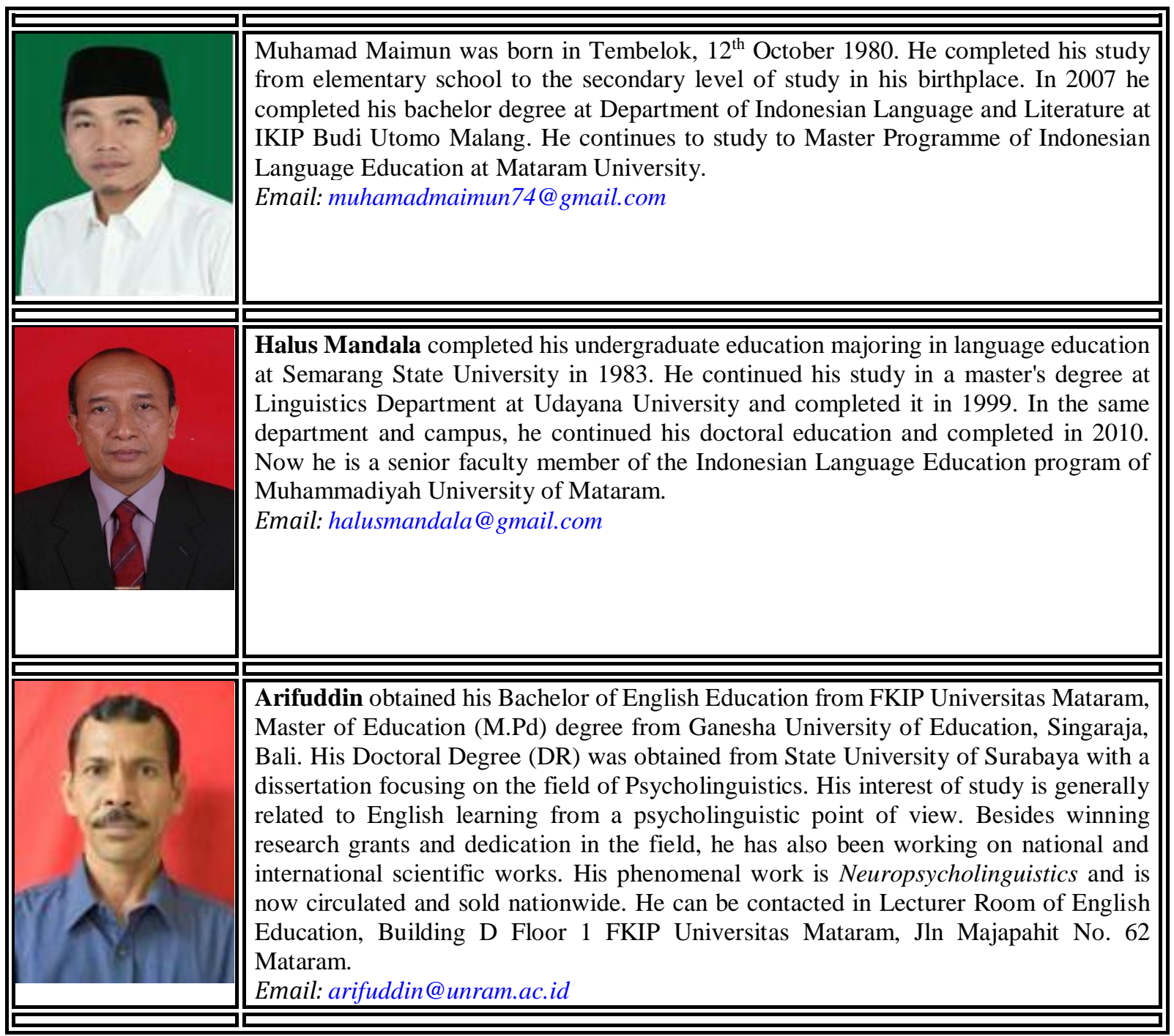

Maimun, M., Mandala, H., \& Arifuddin, -. (2018). Ideology in tempo magazine advertising: a critical discussion analysis. International Research Journal of Management, IT and Social Sciences, 5(6), 40-51. https://doi.org/10.21744/irjmis.v5n6.336 